\section{Fertigation and Growth of Young 'Hamlin' Orange Trees in Florida}

\author{
Leah E. Willis and Frederick S. Davies \\ Fruit Crops Department, University of Florida, Gainesville, FL 32611
}

\section{D.A. Graetz}

Soil Science Department, University of Florida, Gainesville, FL 32611

Additional index words. ammonium, Citrus sinensis, leaching, microirrigation, nitrate, nutrition

\begin{abstract}
One-year-old 'Hamlin' orange [Citrus sinensis (L.) Osb.] trees on sour orange rootstock (C. aurantium $\mathbf{L}$.) were used to compare various fertigation frequencies and rates with application of granular materials. In Expt. 1, granular fertilizer was applied five times per year or liquid fertilizer was applied five, 10, or 30 times per year at $0.23 \mathrm{~kg} \mathrm{~N} /$ tree per year as an $8 \mathrm{~N}-3.4 \mathrm{P}-6.6 \mathrm{~K}$ formulation. In Expt. 2, an additional treatment of granular and liquid material was applied three times per year, but fertilizer rate and formulation were the same as in Expt. 1. Experiment 3 included the same application frequencies as Expt. 1, but with two rates of $N(0.11$ or $0.06 \mathrm{~kg}$ $\mathrm{N} /$ tree per year). Soil samples were taken from each treatment 1, 4, and 7 days after fertilization at depths of $0-15,16-46$, and $47-76 \mathrm{~cm}$ for nutrient analyses. Trunk diameter, shoot growth, and tree height were similar for all treatments 8 months after planting in Expts. 1 and 2, while trees in Expt. 3 had significantly less growth at the lower rate. Soil $\mathrm{NH}_{4}-\mathrm{N}$ and $\mathrm{NO}_{3}-\mathrm{N}$ concentrations for all liquid treatments within 1 week of fertilization were highest for the five times per year treatment at the 0 - to 15cm depth, but nutrient concentrations of all liquid treatments were similar at the other depths. For most dates and depths, $\mathrm{NH}_{4}-\mathrm{N}$ and $\mathrm{NO}_{3}-\mathrm{N}$ concentrations were similar for both fertilizer rates.
\end{abstract}

In $1988-89, \approx 49,000$ ha of citrus was planted in Florida (Division of Plant Industry, 1990). During planting, $12 \%$ of growers fertilized with liquid fertilizer, while $21 \%$ used fertigation alone or in combination with granular fertilizer after planting (Taylor et al., 1989). Fertigation has several advantages over broadcasted granular fertilizers, including effective placement of nutrients and flexibility in application frequency (Ferguson and Davies, 1989). While fertigation is becoming a widely used method for fertilizing young citrus trees in Florida, no information is available concerning optimum rates or frequencies of application.

In previous research on fertilization of young citrus trees, Rasmussen and Smith (1961) found no effect of application frequency of granular fertilizer on growth of newly planted 'Valencia', 'Hamlin', or 'Pineapple' orange trees. Bester et al. (1977) studied application frequency of broadcast urea and liquid fertilizers on newly planted 'Valencia' orange trees and found that trunk diameter was the same for trees fertigated six times per year compared with broadcasted fertilizer applied four times per year. However, fertigated trees had higher leaf $\mathrm{N}$

Received for publication 26 Feb. 1990. Univ. of Florida Agr. Expt. Sta. Journal Series no. R-00537. The cost of publishing this paper was defrayed in part by the payment of page charges. Under postal regulations, this paper therefore must be hereby marked advertisement solely to indicate this fact. and $\mathrm{Fe}$ concentrations and received $60 \%$ more water than those with the broadcast treatment.

Fertigation frequency and rate may also affect nutrient levels in the soil. Several experiments have been conducted to determine the amount of $\mathrm{NO}_{3}^{-}$losses from leaching. A direct relationship was found between $\mathrm{NO}_{3}^{-}$ concentration in a sandy loam soil and the rate of $\mathrm{N}$ applied to citrus (Dasberg et al., 1983, 1988) and apple trees (Klein and Spieler, 1987). In contrast, Rible and Pratt (1977) did not find a significant correlation between amount of $\mathrm{N}$ applied and $\mathrm{NO}_{3}^{-}$accumulated or leached. Fellows and Brezonik (1981) found that when using fertilizer rates higher than recommended on citrus trees in Florida, nutrient seepage into Conway and Apopka Lakes was increased, as compared to using the recommended rate. However, rates below those recommended were not tested.

Several factors influence leaching of $\mathrm{NO}_{3}^{-}$including climate, soil type, land use, and rate and source of $\mathrm{N}$. When moderate amounts of $\mathrm{N}(211 \mathrm{~g} /$ tree $)$ were applied to young citrus trees, there was $79 \%$ and $89 \%$ $\mathrm{N}$ recovery of the plant/soil system after 6 and 14 weeks, respectively (Hagillih, 1980). Shallow tilling increased $\mathrm{NO}_{3}($ Calvert, 1975; Mansell et al., 1980a, 1980b) and $\mathrm{NH}_{4}^{+}$ (Mansell et al., 1980b) leaching. However, the latter experiment also showed $\mathrm{NH}_{4}^{+}$concentrations decreased within 1 week after fertigation and irrigation. Meek et al. (1970) found $\mathrm{NO}_{3}^{-}$concentration decreased as the soil solution approached the water table. $\mathrm{Ni}$ trate concentrations in the surface water of a well-drained sandy soil were twice as high in the 0 - to $60-\mathrm{cm}$ as in the $60-$ to $120-\mathrm{cm}$ sample depth. "Even greater $\mathrm{NO}_{3}^{-}$concentration differences between the two depths occurred after fertilizer application and were directly influenced by rainfall (Forbes et al., 1974).

Although fertigation has been used for several years, particularly for mature citrus trees, no research has been done in Florida on rate and timing of fertigation for newly planted citrus trees. Our objectives were to determine optimum rates and application frequeney of granular as compared to liquid fertilizers and to monitor movement of $\mathrm{NO}_{3}-\mathrm{N}$ and $\mathrm{NH}_{4}-\mathrm{N}$ through the root zone of young citrus trees.

Fertigation on a Kanapaha fine sand (Expt. 1). Container-grown 'Hamlin' orange trees on sour orange rootstock $(\approx 1.5$ years in the nursery) were obtained from Southern Citrus Nurseries, Dundee, Fla., and planted in Apr. 1987 on double beds (16.75 m width x 0.60$0.75 \mathrm{~m}$ height $\times 85 \mathrm{~m}$ length) at the Horticultural Research Unit near Gainesville, Fla. Soil type was a Kanapaha fine sand (loamy, siliceous, hyperthermic, Grossarenic, Paleaquults) with a loamy or clayey layer starting $\approx 1.2 \mathrm{~m}$ below the soil surface and a water table fluctuating between 0.45 to $1.60 \mathrm{~m}$ from

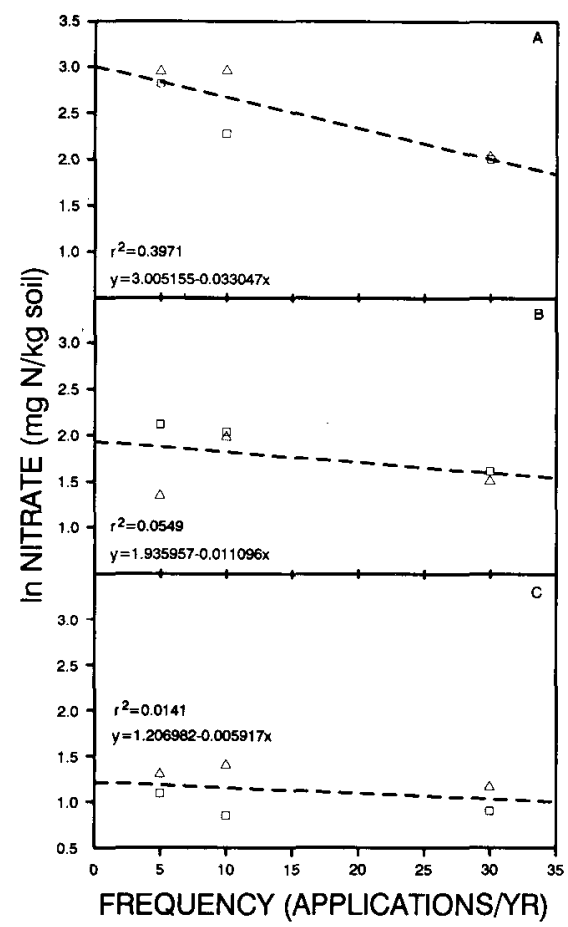

Fig. 1. Fertigation frequency and soil $\mathrm{NO}_{3}-\mathrm{N}$ concentration 1 day after fertigation using two fertilizer rates [0.06 (D) and 0.11 (A) $\mathrm{kg} \mathrm{N} /$ tree per year] at three depths under 'Hamlin' orange trees 8 months after planting. (A) $0-15 \mathrm{~cm}$; (B) $16-46 \mathrm{~cm}$; (C) $47-76 \mathrm{~cm}$. Single regression lines represent combined values for both $\mathrm{N}$ rates. 
Table 1. Effect of fertilizer rate, type, and application frequency on growth of young 'Hamlin' orange trees 8 months after planting on a Kanapaha fine sand with a hard pan $1.2 \mathrm{~m}$ below the soil surface, 1988 (Expt. 3).

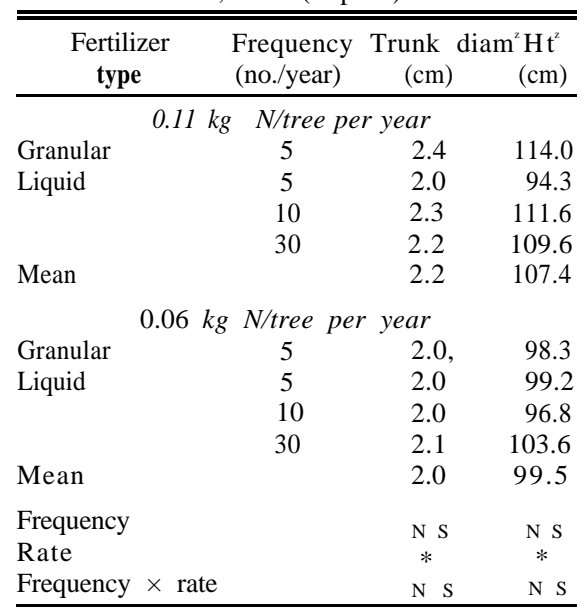

${ }^{2}$ Means of 12 individual tree replicates per treatment.

${ }^{\text {Ns. }}{ }^{*}$ Nonsignificant or significant at $P=0.05$, respectively.

the crest of the bed (Marler, 1988). Trees were watered 2 to $4 \mathrm{~h}$ every other day for 2 weeks using 38 -liter $\cdot \mathrm{h}^{-1} 90^{\circ}$ microsprinklers located $1 \mathrm{~m}$ northwest of the trunk until the trees became established. Treatments included granular fertilizer applied 'five times per year (every 6 weeks), as currently recommended (Koo et al., 1984), or liquid fertilizer applied 30 (weekly), 10 (every 3

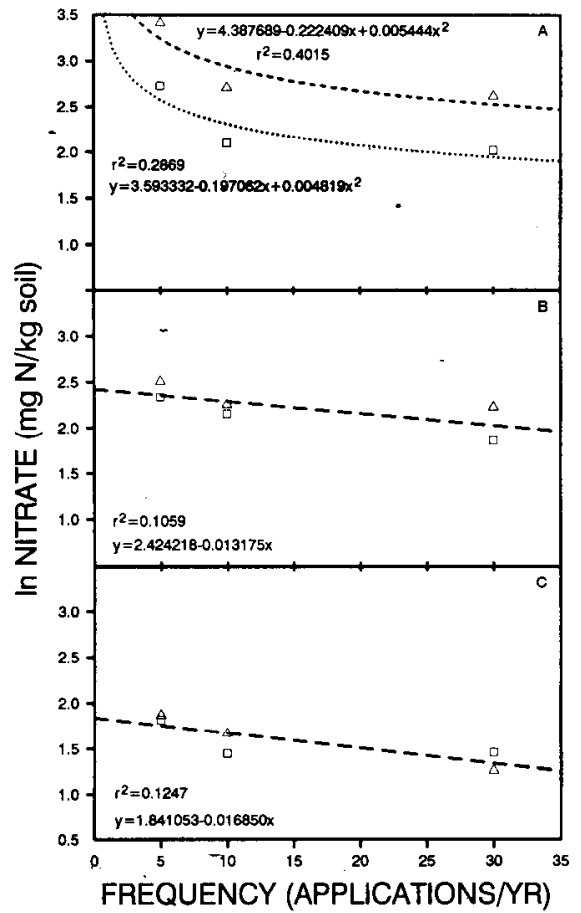

Fig. 2. Fertigation frequency and soil $\mathrm{NO}_{3}-\mathrm{N}$ concentration 4 days after fertigation using two fertilizer rates $[0.06$ ( $\square$ ) and 0.11 (A) $\mathrm{kg} \mathrm{N} /$ tree per year] at three depths under 'Hamlin' orange trees 8 months after planting. (A) $0-15 \mathrm{~cm}$; (B) $16-46 \mathrm{~cm}$; (C) $47-76 \mathrm{~cm}$. Single regression lines represent combined values for both $\mathrm{N}$ rates $(\mathrm{B}$, c ) . weeks), or five times per year (every 6 weeks). In-line 2\% fixed Dosatron injectors (Dosatron International, ClearWater, Fla.) were used to apply liquid fertilizer. The liquid formulation $\left[8 \mathrm{~N}\left(4.85 \% \mathrm{NH}_{4}^{+}, 3.15 \% \mathrm{NO}_{3}^{-}\right) 0 \mathrm{P}\right.$ $6.6 \mathrm{~K}-0.26 \mathrm{Mg}-0.14 \mathrm{Mn}-0.008 \mathrm{Cu}-0.005 \mathrm{~B}]$ was representative of that commonly used by commercial growers and currently recommended (Koo et al., 1984). Total dissolved salts ranged from 300 (well water) to 12,000 (fertigation five times per year) ppm, and no damage to trees was observed. To prevent precipitation of $\mathrm{P}$ in the irrigation lines, fertigated treatments received $213 \mathrm{~g}$ of granular $\mathrm{P} /$ tree per year in five applications that were broadcast by hand within the dripline of each tree. The granular fertilizer was formulated to match the soluble source as closely as possible [ $8 \mathrm{~N}\left(4.0 \% \mathrm{NH}_{4} 4.0 \% \mathrm{NO}_{3}\right)^{-}-3.5 \mathrm{P}$ 6.6K-0.40Mg-0.29Mn-0.008Cu-0.006B].

All trees received $0.23 \mathrm{~kg} \mathrm{~N} /$ tree per year. Trees were arranged in a randomized complete-block design consisting of 24 individual tree samples/block (treatment). Therefore, each block constituted a single replicate for each treatment. Trees were spaced $3.4 \mathrm{~m}$ within rows and $7.9 \mathrm{~m}$ between rows on each double bed.

All trees received the same amount of water, applied either during fertigation or at $20 \%$ soil moisture depletion (SMD), as determined using a Troxler 2601 neutron probe '(Troxler, Raleigh, N. C.) (Marler and Davies, 1990). Liquid fertilizer was injected at the end of an irrigation cycle, with all treatments finishing at the same time to reduce

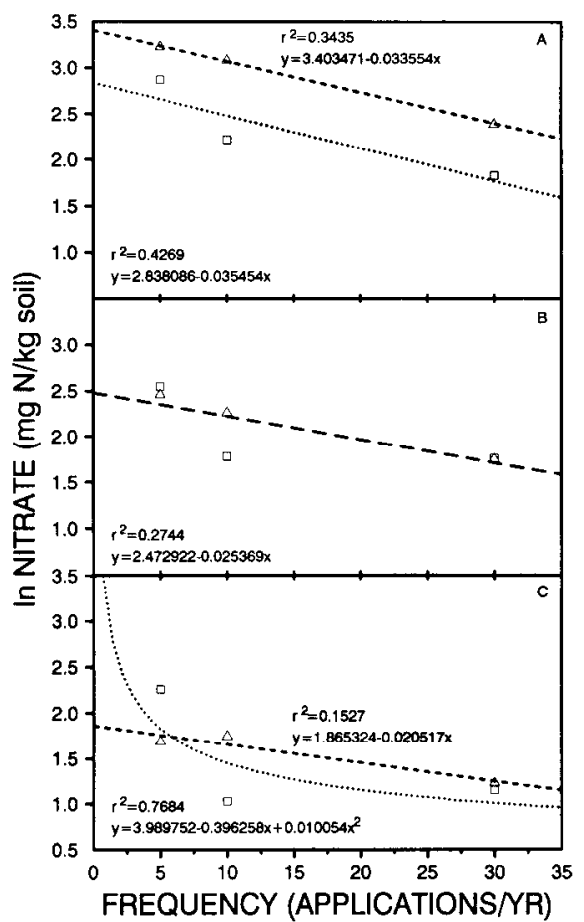

Fig. 3. Fertigation frequency and soil $\mathrm{NO}_{3}-\mathrm{N}$ concentration 7 days after fertigation using two fertilizer rates $[0.06 \square$ ) and 0.11 (A) $\mathrm{kg} \mathrm{N} /$ tree per year] at three depths under 'Hamlin' orange trees 8 months after planting. (A) $0-15 \mathrm{~cm}$; (B) $16-46 \mathrm{~cm}$; (C) $47-76 \mathrm{~cm}$. A single regression line represents combined values for both $\mathrm{N}$ rates (B). nutrient leaching after application. Measurements included preplant soil analysis, tree height and trunk diameter at planting and after each growth flush (three/year) for all trees, and leaf nutrient analysis, and shoot length and number after each growth flush for 10 trees/treatment (Marler and Davies, 1990). Whole-plant fresh and dry weights were taken in Dec. 1987.

Fertigation on an Arredondo fine sand (Expt. 2). Barerooted 'Hamlin' orange trees on sour orange rootstock $(\approx 2$ years in the nursery) were obtained from Southern Citrus Nurseries and planted in Apr. 1988 at the Fifield Farm, Gainesville. Soil type was an Arredondo fine sand (loamy, siliceous, hyperthermic, Grossarenic, Paleuquults). Treatments included granular fertilizer applied three or five times per year or liquid fertilizer applied three, five, 10, or 30 times per year. Fertilizer analysis and rate were the same as in Expt. 1. Trees were arranged in a randomized complete-block design with four blocks of five single-tree replicates per block and spaced $4.6 \mathrm{~m}$ within rows and $6.1 \mathrm{~m}$ between rows.

All trees received the same amount of water during fertigation and irrigation using 38-liter $\cdot \mathrm{h}^{-1} 90^{\circ}$ microsprinklers located $1 \mathrm{~m}$ northwest of each trunk. Trees were irrigated every 2 days during the first 2 weeks of establishment, every 2 to 4 days the next 6 weeks, and at $20 \%$ SMD for $1.25 \mathrm{~h}$ the remainder of the year. Fertilizer injection times ranged from 7 to $67 \mathrm{~min}$. Tree trunks were wrapped with fiberglass tree wraps to reduce sprouting.

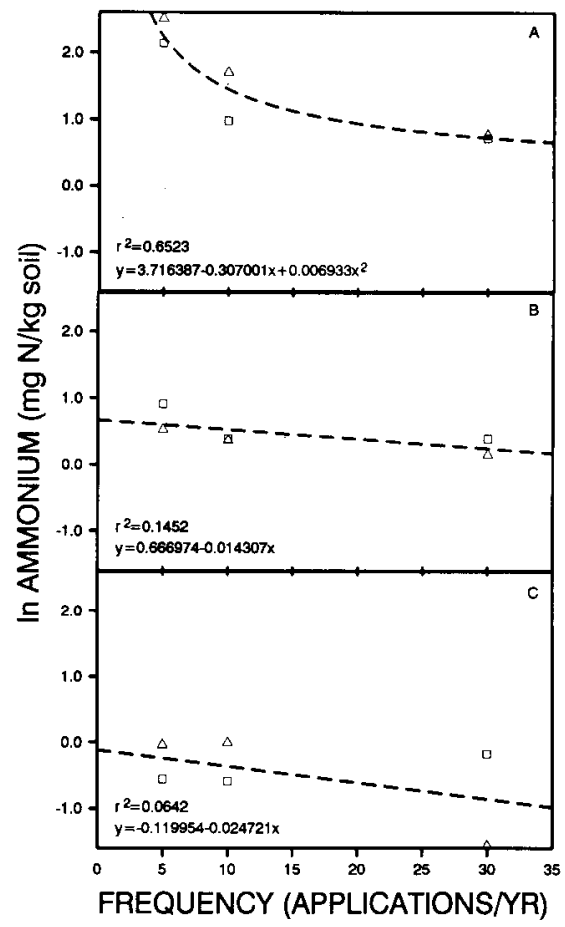

Fig. 4. Fertigation frequency and soil $\mathrm{NH}_{4}-\mathrm{N}$ concentration 1 day after fertigation using two fertilizer rates $[0.06 \square$ ) and 0.11 (A) $\mathrm{kg} \mathrm{N} /$ tree per year] at three depths under 'Hamlin' orange trees 8 months after planting. (A) $0-15 \mathrm{~cm}$; (B) $1646 \mathrm{~cm}$; (C) $47-76 \mathrm{~cm}$. Single regression lines represent combined values for both $\mathrm{N}$ rates. 


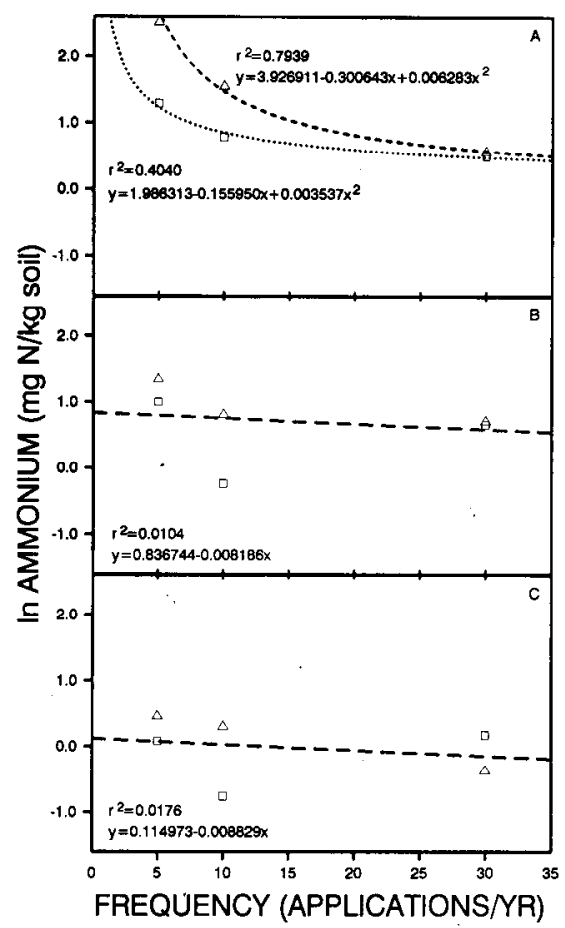

Fig. 5. Fertigation frequency and soil $\mathrm{NH}_{4}-\mathrm{N}$ concentration 4 days after fertigation using two fertilizer rates $[0.06(\square)$ and $0.11(\mathrm{~A}) \mathrm{kg} \mathrm{N} /$ tree per year] at three depths under 'Hamlin' orange trees 8 months after planting. (A) 0-15 cm; (B) $16-46 \mathrm{~cm}$; (C) 47-76 cm. Single regression lines represent combined values for both $\mathrm{N}$ rates (B c).

Measurements included trunk diameter at 2 to $4 \mathrm{~cm}$ above the graft union, height taken at planting and after each growth flush, and leaf nutrient analysis after each growth flush on all trees. Leaf samples were collected from each matured growth flush from the midshoot and included two to three leaves per tree from all trees. Shoot number and length were measured after each flush on eight trees per treatment.

Fertigation at two rates on Kanapaha fine sand (Expt. 3). Barerooted 'Hamlin? orange trees on sour orange rootstock $(\approx 2$ years in the nursery) were obtained from Southern Citrus Nurseries and planted in Apr. 1988 on double beds $(16.75 \mathrm{~m}$ width $\times 0.60-0.75$ $\mathrm{m}$ height $\times 85 \mathrm{~m}$ length) at the Horticultural Research Unit. Site characteristics were the same as those in Expt. 1. Treatments were applied in a $2 \times 4$ factorial arrangement with two fertilizer rates $(0.11$ or $0.06 \mathrm{~kg}$ $\mathrm{N} /$ tree per year) and four fertilizer application frequencies that included a granular treatment applied five times per year or liquid fertilizer applied five, 10, or 30 times per year. Fertilizer analysis, application procedures, irrigation levels, and tree wraps were the same as those in Expt. 2. The same measurements were made as in Expt. 2, except that shoot number and length were measured on 10 trees per treatment. Trees were arranged in a completely randomized design with 12 single-tree replications per treatment. Complete randomization was achieved by placing seven irrigation lines down each row and using individual injectors for each

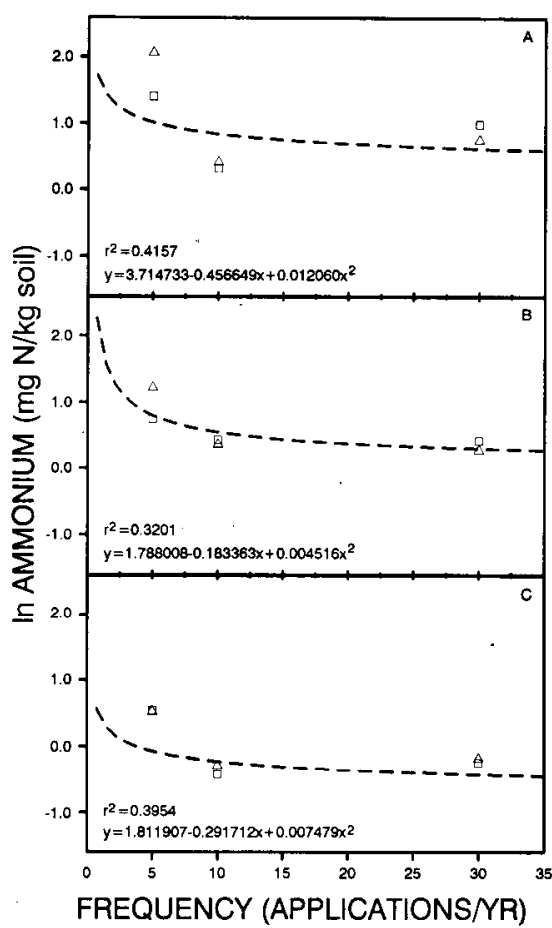

Fig. 6. Fertigation frequency and soil $\mathrm{NH}_{4}-\mathrm{N}$ concentration 7 days after fertigation using two fertilizer rates $[0.06(\square)$ and 0.11 (A) $\mathrm{kg} \mathrm{N} /$ tree per year] at three depths under 'Hamlin' orange trees 8 months after planting. (A) $0-15 \mathrm{~cm}$; (B) $16-46 \mathrm{~cm}$; (C) $47-76 \mathrm{~cm}$. Single regression lines represent combined values for both $\mathrm{N}$ rates.

treatment (Marler and Davies, 1990).

Soil samples were collected to determine accumulation and movement of $\mathrm{NO}_{3}-\mathrm{N}$ and $\mathrm{NH}_{4}-\mathrm{N}$ through the root zone. Samples were taken using a $2.5-\mathrm{cm}$ soil sampling tool at three depths $(0-15,16-46,47-76 \mathrm{~cm})$, with four single-tree replications per treatment. Previous research on this site showed that $80 \%$ of the roots of young 'Hamlin' orange trees were in the top $30 \mathrm{~cm}$ of soil; therefore, samples from the lowest depth were below the root zone (Marler, 1988). Sample dates were 1,4 , and 7 days after the third major fertilization date (6 July 1988), i.e., when all treatments were applied on the same date. Nitrate- $\mathrm{N}$ and $\mathrm{NH}_{4}-\mathrm{N}$ were extracted using $7 \mathrm{~g}$ of soil mixed with $70 \mathrm{ml} 1 \mathrm{~N} \mathrm{KCl}$ and stirred three times in $1 \mathrm{~h}$. The Rapid Flow Analyzer (RFA 300; Alpkem Corp., Clackamas, Ore.) was used for all samples except those with high concentrations of $\mathrm{NH}_{4}-\mathrm{N}$ or $\mathrm{NO}_{3}-\mathrm{N}$, which were run on a Technicon AutoAnalyzer II (Technicon Industrial Systems, Tarrytown, N.Y.).

Growth and leaf nutrient concentrations. No significant differences in trunk diameter and tree height occurred in response to fertilizer frequency or type [granular vs. liquid at the $0.23-\mathrm{kg} \mathrm{N} /$ tree per year rate for Expt. $1(1.5-1.7 \mathrm{~cm}$ and $108-122 \mathrm{~cm}$, respectively) and Expt. 2 (1.8-2.0 cm and 91-99 $\mathrm{cm}$, respectively)]. Trunk diameter and tree height were also similar in response to fertilizer type and application frequency for the 0.11 - or $0.06-\mathrm{kg}$ N/tree per year rates in Expt. 3 (Table 1). The $0.06-\mathrm{kg} \mathrm{N} /$ tree per year rate resulted in significantly less growth than the $0.11-\mathrm{kg} \mathrm{N} /$ tree per year rate, however. There were also no differences in timing of growth flushes, amount of shoot growth, or leaf nutrient concentrations as related to treatments (data not shown). For Expt. 2, leaf nutrient concentrations within optimum ranges included $\mathrm{N}, \mathrm{P}, \mathrm{K}, \mathrm{Mg}, \mathrm{Fe}, \mathrm{Mn}$, and $\mathrm{B}$, while those deficient or low were $\mathrm{Ca}, \mathrm{Zn}$, and $\mathrm{Cu}$. In Expt. 3, leaf nutrients within optimum concentrations were $\mathrm{P}, \mathrm{K}, \mathrm{Mg}$, and $\mathrm{B}$, while nutrients low or deficient included $\mathrm{N}, \mathrm{Ca}$, $\mathrm{Fe}, \mathrm{Mn}, \mathrm{Zn}$, and $\mathrm{Cu}$ (Koo et al., 1984).

Soil nutrient concentrations. Nitrate-N concentrations in the soil were measured for the liquid treatments applied five, 10, and 30 times per year. One day after fertigation, $\mathrm{NO}_{3}-\mathrm{N}$ concentrations were similar for both rates in all three soil depths, as indicated by a single regression equation, and there was a significant but poor linear correlation only for the 0 - to $15-\mathrm{cm}$ depth in response to application frequency (Fig. 1). Four days after fertigation, $\mathrm{NO}_{3}-\mathrm{N}$ levels were similar in the lower two depths, as indicated by a single regression equation (Fig. 2). However, $\mathrm{NO}_{3}$ $\mathrm{N}$ concentrations at the upper depth were significantly higher for the $0.11-\mathrm{kg} \mathrm{N} /$ tree per year rate and both rates showed a significant quadratic trend in response to application frequeney. Treatments applied five times per year led to higher $\mathrm{NO}_{3}-\mathrm{N}$ concentrations than the other application frequencies. Nitrate-N concentrations in the upper and lower depths differed significantly with fertilizer rate 7 days after fertigation (Fig. 3 ). Nitrate- $\mathrm{N}$ concentrations in the first and second depths showed a significant decrease with an increase in application frequency. However, at the lowest depth, $\mathrm{NO}_{3}-\mathrm{N}$ concentration was significantly different in response to application frequency only for the $0.06-\mathrm{kg} \mathrm{N} /$ tree per year fertilizer rate, where levels applied five times per year were significantly higher than those of other application frequencies. There was little accumulation and leaching of $\mathrm{NO}_{3}-\mathrm{N}$ past the root zone into the 47- to $76-\mathrm{cm}$ depth within 7 days after fertigation.

Ammonium-N concentrations 1 day after fertigation were similar for all application frequencies and both rates for the lower two depths, as indicated by a single regression equation (Fig. 4). However, treatments applied five times per year had significantly higher $\mathrm{NH}_{4}-\mathrm{N}$ concentrations compared to 10 and 30 times per year in the $0-$ to $15-\mathrm{cm}$ depth $(P=0.05$, data not shown). Four days after fertigation, $\mathrm{NH}_{4}-\mathrm{N}$ concentrations differed at the first depth in response to fertilizer rate and application frequency, as indicated by a significant quadratic trend (Fig. $5)$. Seven days after fertigation, $\mathrm{NH}_{4}-\mathrm{N}$ concentrations were similar in response to fertilizer rate (Fig. 6), and the five times per year treatment resulted in significantly higher levels of $\mathrm{NH}_{4}-\mathrm{N}$ than the other application frequencies for all depths $(P=0.05$, data not shown). There was little accumulation or movement of $\mathrm{NH}_{4}-\mathrm{N}$ past the root zone into the $47-$ to $76-\mathrm{cm}$ depth within 7 days after fertigation.

Soil $\mathrm{NO}_{3}-\mathrm{N}$ and $\mathrm{NH}_{4}-\mathrm{N}$ concentrations for 
granular materials were $<5$ and $3 \mathrm{mg} \mathrm{N} / \mathrm{kg}$ soil, respectively, suggesting that our sampling procedure did not accurately reflect nutrient concentrations in the soil. In this instance, the distribution of the granules was such that the soil sample did not always contain fertilizer, whereas the liquid formulation was evenly distributed over the fertigated area.

Growth of young 'Hamlin' orange trees did not depend on frequency of fertilizer application or fertilizer type within the limits of this study, using two soil types and planting systems. Nitrogen applied at $0.06 \mathrm{~kg} /$ tree per year significantly limited tree growth, as compared to $0.11 \mathrm{~kg} /$ tree per year. Our results are in agreement with those of Rasmussen and Smith (1961), who found no effect of fertilization frequency on growth of young citrus trees using granular materials. Moreover, our optimum rates are within currently recommended rates for granular materials on young citrus trees (Koo et al., 1984). Dasberg et al. (1988) also observed no effect of fertilizer source (liquid or granular) on growth of mature citrus trees, provided the trees received equal amounts of water. Concentration of $\mathrm{NO}_{3}-\mathrm{N}$ and $\mathrm{NH}_{4}-\mathrm{N}$ at a 0 - to $15-\mathrm{cm}$ depth was significantly higher for trees fertigated five times per year as compared to 30 times per year, with no accumulation and movement of these nutrients past the root zone within 7 days of application. Our results indicate that-growers have flexibility in choosing their fertilizer programs in the first season after planting, allowing them to adjust fertilizer rates and frequencies according to leaf analyses, water quality, and cultural practices. Properly managed fertigation may also reduce ground water pollution, particularly with nitrates, without compromising growth of young trees. In addition, once the fertigation system is in place, cost of application is considerably less for fertigation than for granular materials (Ferguson and Davies, 1989).

\section{Literature Cited}

Bester, D. H.; P.S. Fouche, and G.H. Veldman. 1977. Fertilizing through drip irrigation systems on orange trees. Proc. Intl. Soc. Citriculture 1:46-49.

Calvert, D.V. 1975-. Nitrate, phosphate, and potassium movement into drainage lines under three soil management systems. J. Env. Qual. 4:183186.

Dasberg, S., A. Bar-Akiva, S. Spazisky, and A. Cohen. 1988. Fertigation versus broadcasting in an orange grove. Fert. Res. 15:147-154.

Dasberg, S., H. Bielorai, and J. Emer. 1983. Nitrogen fertigation of Shamouti oranges. Plant \& Soil 75:41-49.

Division of Plant Industry. 1990. Commercial citrus tree inventory. Preliminary report. Florida Agr. Sta. Ser., Orlando.

Fellows, C.R. and P.L. Brezonik. 1981. Fertilizer flux into two Florida lakes via seepage. J. Env. Qual. 10:174-177.

Ferguson, J.J. and F.S. Davies. 1989. Fertilization of young citrus. Florida Coop. Ext. Fact Sheet FC-79.

Forbes, R.B., C.C. Hortenstine, and F.W. Bistline. 1974. Nitrogen, phosphorus, potassium, and soluble salts in the soil solution in a Blanton fine sand. Soil \& Crop Sci. Soc. Fla. 33:202204.
Hagillih, D.A. 1980. The fate of fertilizer-N ap. plied to a Florida citrus soil. PhD Diss., Univ. of Florida, Gainesville. (Diss. Abstr. 8025377).

Klein, I. and G. Spieler. 1987. Fertigation of apples with nitrate or ammonium nitrogen under drip irrigation. H. Nutrient distribution in the soil. Tree performance. Commun. in Soil Sci. Plant Anal. 18:323-339.

Koo, R.C.J., C.A. Anderson, I. Stewart, D.P.H. Tucker, D.V. Calvert, and H.K. Wutscher. 1984. Recommended fertilizers and nutritional sprays for citrus. Fla. Agr. Expt. Sta. Bul. 536D.

Mansell, R.S., W.B. Wheeler, and D.V. Calvert. 1980a. Leaching losses of two nutrients and an herbicide from two sandy soils during transient drainage. Soil Sci. 130:140-150.

Mansell, R.S., H.M. Selim, D.V. Calvert, E.H. Stewart, L.H. Allen, D.A. Graetz, J.G.A. Fiskell, and J.S. Rogers. 1980b. Nitrogen and water distributions in fertilized sandy soil during irrigation and drainage. Soil Sci. Soc. Amer. J. 44:95-102.
Marler, T.E. 1988. Growth of young 'Hamlin' orange trees as influenced by microsprinkler irrigation, fertilization, and nursery tree type. $\mathrm{PhD}$ Disa., Univ. of Florida. Gainesville. (Diss. Abstr. 8923588).

Marler, T.E. and F.S. Davies. 1990. Microsprinkler irrigation and growth of young 'Hamlin' orange trees. J. Amer. Soc. Hort. Sci. 115:4551:

Meek, B.D., L.B. Grass, L.S. Willardson, and A.J. Mackenzie. 1970. Nitrate transformations in a column with a controlled water table. Soil Sci. Soc. Amer. Proc. 31:235-239.

Rasmussen, G.K. and P.F. Smith. 1961. Evaluation of fertilizer practices for young orange trees. Proc. Fla. State Hort. Soc. 74:90-95.

Rible, J.M. and P.F. Pratt. 1977. Nitrate-nitrogen in the unsaturated zone below irrigated fields. Calif. Agr. 31:28-29.

Taylor, C.L., J.J. Ferguson, G.D. Israel, and W.R. Summerhill. 1989. Citrus young tree care. Inst. Food \& Agr. Sci., Univ. of Fla. Bul. PE-7. 